\title{
Best time and doses to associate chemical and biological control of the coffee berry borer in highland region, Brazil
}

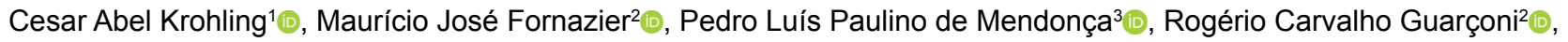 \\ David dos Santos Martins ${ }^{4}\left(\mathbb{D}\right.$, Fabiano Tristão Alixandre ${ }^{5}$, Rodrigo da Silva Dias $^{6}{ }^{\infty}$, Fernanda Latanze Mendes Rodrigues ${ }^{7}[$
}

${ }^{1}$ Instituto Capixaba de Pesquisa, Assistência Técnica e Extensão Rural/INCAPER, Marechal Floriano, ES, Brasil ${ }^{2}$ Instituto Capixaba de Pesquisa, Assistência Técnica e Extensão Rural/INCAPER, Venda Nova do Imigrante, ES, Brasil ${ }^{3}$ BASF Brasil, São Paulo, SP, Brasil

${ }^{4}$ Fundação de Amparo à Pesquisa e Inovação do Espírito Santo/FAPES, Vitória, ES, Brasil

${ }^{5}$ Universidade Federal do Espírito Santo/UFES, Alegre, ES, Brasil

${ }^{6}$ Inove Consultoria, Venda Nova do Imigrante, ES, Brasil

${ }^{7}$ Programa de Educação Continuada em Economia e Gestão de Empresas/PECEGE, Piracicaba, SP, Brasil

Contact authors: cesar.kro@hotmail.com; mauriciofornazier@gmail.com; pedro.paulino-mendonca@basf.com; rogerio.guarconi@gmail.com; davidentomol@gmail.com;

fabianotristaoalixandre@hotmail.com; rodrigodasilvadias@yahoo.com.br; fernandamendes@pecege.com

Received in June 302021 and approved in October 14, 2021

\section{ABSTRACT}

The coffee berry borer (CBB) Hypothenemus hampei (Ferrari) (Coleoptera: Curculionidae) causes significant damage to yield and quality of coffee beans. Cultural measures are important however, chemical and biological control must be adopted within an integrated CBB management system in order to prevent its damage mainly in larger areas. This study aimed to evaluate different doses and times of spray of the chemical insecticide metaflumizone and its association to the entomopathogenic fungus Beauveria bassiana as a tool to the management of CBB in Arabica coffee. The study was carried out in a high dense crop of Arabica coffee cultivar Catuaí Vermelho at $700 \mathrm{~m}$ altitude in the highlands of Espírito Santo state, Brazil. The experimental design used was randomized blocks with eleven treatments, four replications and plots of ten plants. Seven evaluations were carried out by sampling the berries in the upper, middle and two sides of the coffee trees. Metaflumizone at a total dose of $3.5 \mathrm{~L} \mathrm{ha}^{-1}$ showed high performance for the control of CBB under field conditions in regions of high altitude. The association of metaflumizone with $B$. bassiana reduced a mean of $88.5 \%$ the infestation level of CBB in the post-harvested coffee beans and it can be used as one of the tools for the Integrated Management of CBB under field conditions. Beauveria bassiana can be associated with metaflumizone to control CBB as a complementary spray in March and at a dose of $2.0 \mathrm{~kg} \mathrm{ha}^{-1}$ and should be also used in the Integrated Management of CBB. The monitoring of CBB population must be carried out and the first spraying with chemical or biological insecticide must be started at the recommended control level and in the transit season of $C B B$ when flying adults are exposed.

Key words: Beauveria bassiana; Field conditions; Insect pest management; Metaflumizone; Monitoring

\section{INTRODUCTION}

Brazil is the world's largest producer and exporter of coffee and this is a very important food for Brazilian agribusiness. The total area planted with coffee in Brazil was 2.16 million hectares with a total production of 3,784,674 $\mathrm{t}$ in 2020 (Companhia Nacional de Abastecimento - CONAB, 2020). Yield is influenced by several factors such as temperature, rainfall, relative humidity, the cultural treatments (liming, fertilization, control of herbs, pruning, etc.), cultivars, type of soil, irrigation, control of pests and diseases, among others (Matiello et al., 2020). Pests are one of the most important factors that can reduce coffee crop yield and bean quality with emphasis on the coffee leaf miner Leucoptera coffella (Guérin-Mèneville \& Perrottet) (Lepidoptera: Lyonetiidae) and the coffee berry borer (CBB) Hypothenemus hampei (Ferrari) (Coleoptera: Curculionidae) considered the most important pest of coffee worldwide (Fornazier et al., 2019; Reis, 2010; Vega; Infante; Johnson, 2015). Initial CBB population, periods of rainfall, temperature and implementation of its correct management are factors of great importance in
CBB management under field conditions (Souza; Reis, 1997; Matiello et al., 2020).

CBB attacks green, ripe and dried fruits of Arabica coffee (Coffea arabica L.) as well as conilon (Coffea canephora Pierre and ex-Froehner) in all producing countries. The damage caused by CBB can be due to the fall of berries, reduced weight and loss of quality (aspect, type, drink) of damaged beans (Fornazier et al., 2019; Matiello et al., 2020). It can cause yield losses of $30-35 \%$ with up to $100 \%$ of damaged berries at harvest time and its damage can be greater with the delay of the harvest (Barrera, 2008).

Berries that remain on the plant or even on the ground after harvest favor CBB' reproduction, allowing their transfer from one crop to another. Conditions such as shading and high dense crops, wet season, abandoned crops, uneven flowering, dry season in the months of December and January also favor their survival, which may increase the infestation level of CBB in the following year's harvest. Higher temperature regions, such as found in the states of Rondônia, Southern Bahia, Vale do Rio Doce in Minas Gerais and Northern Espírito Santo, Brazil decreases the pest cycle and increases the number of 
CBB generations with greater damage, becoming a serious problem for coffee farmers (Fornazier et al., 2019; Matiello et al, 2020). Controlling CBB is not an easy task because most of the CBB's life cycle occurs within the coffee berries. Normally, the coffee berry becomes susceptible to CBB attack when its dry weight is $20 \%$ or more which occurs when the fruit reaches between 100 and 150 days of development, depending on the altitude (Montoya; Cárdenas, 199 \&). Insecticide spraying is the most used control method for $\mathrm{CBB}$, mainly in extensive coffee crops. However, it is recommended that before starting $\mathrm{CBB}$ control, fruit sampling should be carried out and chemical or biological control should only be started when the infestation level of berries reaches 1.0 to 3.0\% (Matiello et al, 2020).

One of the major problems to control CBB was the ban on the marketing of the active ingredient Endosulfan in Brazil. However, we can verify that new active ingredients have been registered in this country to control of this pest such as azadiractin, Beauveria bassiana (Order: Family?), cyantraniliprole, chlorantraniliprole, chlorpyrifos, etiprole, etofenproxy, metaflumizone and mixtures of active ingredients. Metaflumizone is an active ingredient belonging to the chemical group semicarbazone and is efficient for the control of insects of different orders. It acts on the nervous system of insects, blocks sodium channels, causes paralysis without the need to be metabolically activated inhibiting the insect's food and causing its death. It is classified by the Insecticide Resistance Action Committee (IRAC) as the only insecticide belonging to the 22B group. Its main characteristics are the high activity in the control of insects, low toxicity for beneficial insects and mammals, in addition to the low environmental risk (Agrofit, 2021a; Salgado; Hayashi, 2007).

The fungi $B$. bassiana, Spicaria javanica and Metharizium anisoplae (Order: Family for those fungi) have been shown to be efficient for the control of CBB colonizing the adults (Mota et al., 2017). Beauveria bassiana is a fungus that has no negative impact on humans, other animals and the environment and has a low impact on beneficial insects (Aristizábal, 2018). Formulations of this entomopathogenic fungus are registered in Brazil based on five strains (Agrofit, 2021a). The objective of this study was to evaluate the possibility of combining the use of metaflumizone in alternation of spraying with $B$. bassiana for control of CBB in different doses and spraying times in Arabica coffee under the climatic conditions of highland region enabling new options for $\mathrm{CBB}$ integrated management.

\section{MATERIAL AND METHODS}

\subsection{Study area and treatments}

The study was carried out in a dense crop $(2.0 \mathrm{~m} \mathrm{x}$ $0.8 \mathrm{~m}$ ) of Arabica coffee cultivar Catuaí Vermelho IAC-44, in a Red Yellow Latosol (LVA) (Empresa Brasileira de Pesquisa Agropecuária - EMBRAPA, 2013), municipality of Marechal Floriano (20²6’43, 77’'S; 4046’45,50”W), Espírito Santo state, Brazil. The coffee crop used was 6 years old, pruned and conducted with two orthotropic branches per plant. The adopted crop's cultural procedures were those contained in Alixandre et al. (2020). The three most significant blossoms of this coffee crop occurred on October 7 and 31, and November 11, 2018. The experimental design used was randomized blocks, four replications with 10 plants. The chemical metaflumizone $\left(1.5 ; 2.0 \mathrm{~L} \mathrm{ha}^{-1}\right)$ and the biological insecticide B. bassiana PPRI $5339\left(0.75 ; 1.0 ; 2.0 \mathrm{~kg} \mathrm{ha}^{-1}\right)$ were used in four combinations of spraying time and one control, totaling 11 treatments (Table 1). Sprayings were carried out in early January, February, March and April 2019. A manual backpack sprayer (capacity of $20 \mathrm{~L}$ ) was used with $400 \mathrm{~L} \mathrm{ha}^{-1}$ of solution. The climate data at the experiment site (rainfall, average temperature and average relative humidity) were obtained biweekly from September 2018 to June 2019 using a La Crosse Pro WS 2800 mini-station.

\subsection{Method of sampling and evaluation}

Seven samplings were carried out to measure CBB infestation level. Each sampling was done through the collection of berries in green and/or cherry stage, in the upper, middle and both sides of the coffee plants according to the stage of maturation in each sampling. The berries were removed randomly from the branches of the coffee tree.

The first sampling was carried out in early January 2019, before the first spraying of chemical/biological insecticides; the 2nd sampling was carried out in February 2019 before the 2nd spraying; the 3rd sampling was done in March 2019 before the 3rd spraying; the 4th sampling was carried out in April 2019 before the 4th spraying, and the 5th evaluation was carried out 30 days after the 4th spraying. The 6 th evaluation was carried out on April 23, 2019, at the time recommended for the harvest when more than $80 \%$ of cherry berries was found. On that same date the fruits of the useful plants of the plots were harvested, dried and peeled.

On June 15, 2019, $100 \mathrm{~g}$ of beans from each plot were sampled to count the number of healthy and attacked by CBB. In each of the samplings, at least 200 berries were collected per plot. One hundred of these fruits were randomly chosen and evaluated. The berries bored by CBB were separated and opened to check for the presence of live insects (eggs, larvae, adults) within them.

Abbott's formula (1925) was used to calculate the control efficiency $(\mathrm{CE})$ of insecticides in controlling $\mathrm{CBB}$.

$(C E)=[(T-t) \times 100] / T$, where $T$ is the number of live $\mathrm{CBB}$ berries in the control, and $\mathrm{t}$ is the number of live $\mathrm{CBB}$ berries in each treatment. 
Table 1: Treatments (Treats), spraying times and doses of chemical and biological active ingredients for coffee berry borer control, Marechal Floriano, Espírito Santo state, Brazil, 2019.

\begin{tabular}{|c|c|c|c|c|c|c|}
\hline \multirow{2}{*}{ Treats } & \multirow{2}{*}{ Chemical/biological active $\left(\mathrm{L} \mathrm{ha}^{-1}\right)$} & \multicolumn{4}{|c|}{ Spraying times } & \multirow{2}{*}{ Total dose $\left(\mathrm{kg}\right.$ or $\left.\mathrm{L} \mathrm{ha}^{-1}\right)$} \\
\hline & & 01 jan & $10 \mathrm{feb}$ & 09 mar & $06 \mathrm{apr}$ & \\
\hline $\mathrm{T} 1$ & Testemunha & - & - & - & - & - \\
\hline $\mathrm{T} 2$ & Metaflumizone & 2.00 & 1.50 & - & - & 3.50 \\
\hline \multirow{2}{*}{$\mathrm{T} 3$} & Metaflumizone & - & 2.00 & 1.50 & - & 3.50 \\
\hline & Beauveria bassiana & 1.00 & - & - & - & 1.00 \\
\hline \multirow{2}{*}{$\mathrm{T} 4$} & Metaflumizone & - & 2.00 & 1.50 & - & 3.50 \\
\hline & Beauveria bassiana & 2.00 & - & - & - & 2.00 \\
\hline \multirow{2}{*}{$\mathrm{T} 5$} & Metaflumizone & 2.00 & - & 1.50 & - & 3.50 \\
\hline & Beauveria bassiana & - & 1.00 & - & - & 1.00 \\
\hline \multirow{2}{*}{ T6 } & Metaflumizone & 2.00 & - & 1.50 & - & 3.50 \\
\hline & Beauveria bassiana & - & 2.00 & - & - & 2.00 \\
\hline \multirow{2}{*}{$\mathrm{T} 7$} & Metaflumizone & & 2.00 & 1.50 & - & 3.50 \\
\hline & Beauveria bassiana & 0.75 & - & - & - & 0.75 \\
\hline \multirow{2}{*}{$\mathrm{T} 8$} & Metaflumizone & 2.00 & - & 1.50 & - & 3.50 \\
\hline & Beauveria bassiana & - & 0.75 & - & - & 0.75 \\
\hline \multirow{2}{*}{ T9 } & Metaflumizone & - & 1.50 & 1.00 & 1,00 & 3.50 \\
\hline & Beauveria bassiana & 1.00 & - & - & - & 1.00 \\
\hline \multirow{2}{*}{$\mathrm{T} 10$} & Metaflumizone & - & 2.00 & 1.50 & - & 3.50 \\
\hline & Beauveria bassiana & 1.00 & - & - & - & 1.00 \\
\hline \multirow{2}{*}{$\mathrm{T} 11$} & Metaflumizone & 2.00 & 1.50 & - & - & 3.50 \\
\hline & Beauveria bassiana & - & - & 2.00 & - & 2.00 \\
\hline
\end{tabular}

\subsection{Experimental Design}

The experiment was carried out in a randomized block design with four replications and ten plants per plot, in the subplot scheme over time. The plots were composed by eleven treatments and the subplots by seven evaluation times. The number of live CBB data was transformed by the function $\mathrm{y}=\sqrt{x+0.5}$ and subjected to analysis of variance; the contrasts of means were compared by the Scheffé test $(p<0.05)$. The regression models were tested by the $F$ test and the parameters by the $t$ test. The program $\mathrm{R}$ ( $\mathrm{R}$ Core Team, 2019) was used for the statistical analyzes.

Contrasts evaluated:

$C_{1}=10 \widehat{m_{1}}-\widehat{m_{2}}-\widehat{m_{3}}-\widehat{m_{4}}-\widehat{m_{4}}-\widehat{m_{6}}-\widehat{m_{7}}-\widehat{m_{8}}-\widehat{m_{9}}-\widehat{m_{10}}-\widehat{m_{11}}$, used to check whether the control efficiency of the different treatments differed from the control;

$C_{2}=9 \widehat{m_{2}}-\widehat{m_{3}}-\widehat{m_{4}}-\widehat{m_{4}}-\widehat{m_{6}}-\widehat{m_{7}}-\widehat{m_{8}}-\widehat{m_{9}}-\widehat{m_{10}}-\widehat{m_{11}}$, used to verify the need to use the biological insecticide B. bassiana in alternation with the chemical insecticide metaflumizone;

$C_{3}=\widehat{m_{7}}-\widehat{m_{8}}$, used to check the most suitable time to spray $B$. bassiana $\left(0.75 \mathrm{~kg} \mathrm{ha}^{-1}\right)$;
$C_{4}=\widehat{m_{3}}+\widehat{m_{9}}+\widehat{m_{10}}-3 \widehat{m_{5}}$, used to check which time of spraying (1 or 2$)$ is most suitable to spray B. bassiana $(1.0 \mathrm{~kg}$ ha' ${ }^{-1}$;

$C_{5}=\widehat{m_{4}}-\widehat{m_{6}}$, used to check which time of spraying (1 or 2) is most suitable to spray $B$. bassiana $\left(2.0 \mathrm{~kg} \mathrm{ha}^{-1}\right)$;

$C_{6}=\widehat{m_{4}}-\widehat{m_{11}}$; used to check which time of spraying (1 or 3) is most suitable to spray $B$. bassiana $\left(2.0 \mathrm{~kg} \mathrm{ha}^{-1}\right)$;

$C_{7}=\widehat{m_{6}}-\widehat{m_{11}}$; used to check which time (2 or 3 ) is most suitable to spray $B$. bassiana $\left(2.0 \mathrm{~kg} \mathrm{ha}^{-1}\right)$;

$C_{8}=2 \widehat{m_{7}}+2 \widehat{m_{8}}-\widehat{m_{3}}-\widehat{m_{9}}-\widehat{m_{10}}-\widehat{m_{5}}$; used to check the best dose of B. bassiana $\left(0.75\right.$ or $\left.1.0 \mathrm{~kg} \mathrm{ha}^{-1}\right)$, regardless of the time of spraying;

$C_{9}=3 \widehat{m_{7}}+3 \widehat{m_{8}}-2 \widehat{m_{4}}-\widehat{2 m_{6}}-2 \widehat{m_{11}}$; used to check the best dose of B. bassiana $\left(0.75\right.$ or $\left.2.0 \mathrm{~kg} \mathrm{ha}^{-1}\right)$, regardless of the spraying time;

$C_{10}=3 \widehat{m_{3}}+3 \widehat{m_{9}}+3 \widehat{m_{10}}+3 \widehat{m_{5}}-4 \widehat{m_{4}}-\widehat{4 m_{6}}-4 \widehat{m_{11}}$, used to check the best dose of $B$. bassiana ( 1.0 or $\left.2.0 \mathrm{~kg} \mathrm{ha}^{-1}\right)$, regardless of spraying time;

The contrasts were applied in each of the six sampling times, and together for those times aiming to verify the CE. 


\section{RESULTS}

The live $\mathrm{CBB}$ infestations found in the previous evaluation (January 01 ) varied from $2.5 \%$ to $3.5 \%$, and the average initial infestation level was $3.23 \%$ (Table 2). However, the $\mathrm{C} 1$ contrast applied at this first evaluation prove be nonsignificant by the Scheffé test $(p>0.05)$, so no differences were found between the mean of the control and mean of the other treatments (Table 3). Thus, the calculation of CE could be performed using the Abbott's formula (1925) without the need to correct $\mathrm{CE}$ based on the initial infestations. There was a difference in $\mathrm{CBB}$ infestations between the control and the other 10 treatments in the evaluations carried out from February to May, confirmed by the $\mathrm{C} 1$ contrast (Table 3). Also, significant differences were found between the means of the different live $\mathrm{CBB}$ infestations level in the control (T1) when compared to the means of live CBB infestations in all treatments (Table 4). The $\mathrm{C} 1$ contrasts are presented for all times of evaluation because they were statistically significant by the Scheffé test $(\mathrm{p}<0.05)$ (Table 3). The other contrasts $\mathrm{C} 2$ to $\mathrm{C} 10$ are not shown because they were not statistically significant $(p>0.05)$.

An increase in the population of $\mathrm{CBB}$ along the experiment was observed according to the data obtained in the control treatment (Table 2). The population peak of CBB was reached in early March in the control (T1) when $11.5 \%$ of the berries were damaged by $\mathrm{CBB}$ and with the presence of live larvae. The infestation rates of live $\mathrm{CBB}$ in the control were ever above the level determined for $\mathrm{CBB}$ control throughout berries samplings (Figure 1).

No significant difference was observed by the $\mathrm{C} 2$ contrast for the mean rates of live $\mathrm{CBB}$ infestations level in the sampling performed 30 days after the first spraying, where only one spray of $B$. bassiana $\left(0.75 ; 1.00 ; 2.00 \mathrm{~L} \mathrm{ha}^{-1}\right)$ or metaflumizome (2.0 L ha-1) had been done (Table 2).

The CE on the second evaluation date (February 10) ranged from $52.9 \%$ (T11) to $94.1 \%$ (T6) and only the T5, T6 treatments showed CE greater than $80 \%$. However, all treatments, excluding T11 (78.9\%) showed CE greater than $80 \%$ in the third sample (March 09). Variations in CE were observed in the other samplings, however, always above $70 \%$. In the sampling carried out on May 4, after all combinations of doses and spraying times have been applied, most of these treatments showed CE above $80 \%$, excluding T3 and T4 both with CE of $71.4 \%$. The treatments T2, T7, T8 and T11 may be highlighted with CE $>95 \%$. However, the variations in $\mathrm{CE}$ among the treatments showed a little influence on CBB infestation rates and $\mathrm{CE}$ in post-harvest sampling (Table 2). At this time, all treatments showed CE greater than $85 \%$. Spraying with metaflumizome with or without the association of B. bassiana managed to reduce the post-harvest infestation of $\mathrm{CBB}$-damaged beans to rates from $0.5 \%$ to $0.8 \%$ (average $=0.58 \%$ ) in all treatments, differing from control (T1) (5.0\%) (Figure 2).

The alternation of the spraying time of $B$. bassiana as well as the alternation of doses of metaflumizome did not influence the partial CE in the 2nd, 3rd, 4th, 5th and 6th evaluations and in the evaluation performed in post-harvest (Table 4). Metaflumizome at the accumulated dose of $3.5 \mathrm{~L} \mathrm{ha}^{-1}$, alone or alternating with any of the doses used of B. bassiana $\left(0.75 ; 1.00 ; 2.00 \mathrm{~L} \mathrm{ha}^{-1}\right)$ was efficient for controlling CBB regardless of the alternation of spraying times ( $\mathrm{C} 2$ contrast) (Figure 2). The C3, C4 and C5 contrasts were applied in order to compare the first two spraying seasons for B. bassiana at

Table 2: Treatments (Treats), insecticide doses, spraying times and berries percentage $(\% \mathrm{I})$ with live borer (mean \pm standard error) of the coffee borer and control efficiency (\% CE) in the different samplings. Marechal Floriano, Espírito Santo state, Brazil, 2019.

\begin{tabular}{|c|c|c|c|c|c|c|c|c|c|c|c|c|c|}
\hline \multirow{3}{*}{ Treats } & \multicolumn{13}{|c|}{ Date of evaluations } \\
\hline & \multirow{2}{*}{$\frac{\mathrm{Jan} / 01 / 2019}{\% \mathrm{I}}$} & \multicolumn{2}{|c|}{$\mathrm{Feb} / 10 / 2019$} & \multicolumn{2}{|c|}{ Mar/09/2019 } & \multicolumn{2}{|c|}{ Apr/06/2019 } & \multicolumn{2}{|c|}{ May/04/2019 } & \multicolumn{2}{|c|}{ May/23/2019 } & \multicolumn{2}{|c|}{ Jun/15/2019 } \\
\hline & & $\% \mathrm{I}$ & $\% \mathrm{CE}^{*}$ & $\% \mathrm{I}$ & $\% \mathrm{CE}$ & $\% \mathrm{I}$ & $\% \mathrm{CE}$ & $\% \mathrm{I}$ & $\% \mathrm{CE}$ & $\%$ I & $\% \mathrm{CE}$ & $\% \mathrm{I}$ & $\% \mathrm{E}$ \\
\hline T1 & $3.5 \pm 0.3$ & $4.3 \pm 1.0$ & - & $11.5 \pm 2.9$ & - & $5.0 \pm 0.4$ & - & $5.0 \pm 0.4$ & - & $7.3 \pm 1.0$ & - & $5.0 \pm 0.4$ & - \\
\hline $\mathbf{T 2}$ & $3.3 \pm 0.5$ & $1.0 \pm 0.4$ & 76.5 & $1.3 \pm 0.5$ & 89.1 & $1.3 \pm 0.3$ & 75.0 & $0.8 \pm 0.3$ & 85.0 & $0.5 \pm 0.5$ & 95.2 & $0.5 \pm 0.3$ & 90.0 \\
\hline T3 & $3.3 \pm \cdot .3$ & $1.3 \pm 0.3$ & 70.6 & $0.8 \pm 0.5$ & 93.5 & $1.3 \pm 0.5$ & 75.0 & $1.0 \pm 0.4$ & 90.0 & $3.8 \pm 0.3$ & 71.4 & $0.8 \pm 0.3$ & 85.0 \\
\hline T4 & $3.5 \pm 0.3$ & $1.3 \pm 0.3$ & 70.6 & $1.0 \pm 0.6$ & 91.3 & $0.5 \pm 0.5$ & 90.0 & $0.5 \pm 0.3$ & 90.00 & $3.0 \pm 1.1$ & 71.4 & $0.5 \pm 0.3$ & 90.0 \\
\hline T5 & $3.5 \pm \cdot .7$ & $0.5 \pm 0.3$ & 88.2 & $1.8 \pm 0.9$ & 84.8 & $0.5 \pm 0.3$ & 90.0 & $0.5 \pm 0.3$ & 90.00 & $1.5 \pm 0.7$ & 90.5 & $0.5 \pm 0.3$ & 90.0 \\
\hline T6 & $3.5 \pm 0.7$ & $0.3 \pm 0.3$ & 94.1 & $1.0 \pm 0.6$ & 91.3 & $1.0 \pm 0.4$ & 80.0 & $1.0 \pm 0.4$ & 80.00 & $2.8 \pm 1.3$ & 81.0 & $0.5 \pm 0.5$ & 90.0 \\
\hline $\mathbf{T 7}$ & $3.5 \pm \cdot .5$ & $1.3 \pm 0.5$ & 70.6 & $2.0 \pm 0.8$ & 82.6 & $0.5 \pm 0.3$ & 90.0 & $0.5 \pm 0.3$ & 90.00 & $1.8 \pm 0.6$ & 95.2 & $0.8 \pm 0.3$ & 85.0 \\
\hline T8 & $3.5 \pm 0.3$ & $1.5 \pm 0.3$ & 64.7 & $1.8 \pm 0.9$ & 84.8 & $0.5 \pm 0.3$ & 90.0 & $0.3 \pm 0.3$ & 95.00 & $1.3 \pm 0.8$ & 95.2 & $0.5 \pm 0.5$ & 90.0 \\
\hline T9 & $3.0 \pm 0.4$ & $2.0 \pm 0.4$ & 52.9 & $2.3 \pm 0.6$ & 80.4 & $1.0 \pm 0.4$ & 80.0 & $0.5 \pm 0.3$ & 90.0 & $1.8 \pm 0.6$ & 90.5 & $0.8 \pm 0.3$ & 85.0 \\
\hline T10 & $2.8 \pm 0.3$ & $1.0 \pm 0.4$ & 76.5 & $1.0 \pm \cdot .6$ & 91.3 & $0.8 \pm \cdot .3$ & 85.0 & $0.8 \pm \cdot .3$ & 85.0 & $2.0 \pm 0.8$ & 90.5 & $0.5 \pm 0.3$ & 90.0 \\
\hline T11 & $2.5 \pm \cdot .3$ & $2.0 \pm 0.4$ & 52.9 & $2.5 \pm \cdot .7$ & 78.9 & $0.5 \pm 0.3$ & 90.0 & $0.8 \pm 0.5$ & 85.0 & $3.0 \pm 0.7$ & 95.2 & $0.5 \pm 0.3$ & 90.0 \\
\hline
\end{tabular}

* Control efficiency calculated by Abbott's formula (1925). 
doses of $0.75,1.0$ and $2.0 \mathrm{~kg} \mathrm{ha}^{-1}$, however, these contrasts were not shown significant (Table 4). The best association of B. bassiana with metaflumizone was performed at the dose of $2.0 \mathrm{~kg} \mathrm{ha}^{-1}$ in the spraying of initial March by using the C6 and C7 contrasts that compared spraying times 1, 2 and 3 in pairs for this parameter. Beauveria bassiana at the doses of 0.75 and $1.00 \mathrm{~kg} \mathrm{ha}^{-1}$ did not differ from each other, but differed from the dose of $2.0 \mathrm{~kg} \mathrm{ha}^{-1}$, and this higher dose was the best when compared by the $\mathrm{C} 8, \mathrm{C} 9$ and $\mathrm{C} 10$ contrasts regardless of the spraying time (Table 4 ).

\section{DISCUSSION}

The factors that have most influenced CBB infestation level are infested berries that fall into the soil and those that remain on the plants due to the different flowering that occur in the coffee tree and act as a natural repository for CBB. $\mathrm{CBB}$ adults migrate to new developing berries according to the natural conditions of temperature and rainfall during and after the harvest season (Fornazier et al., 2019). It is necessary to know the $\mathrm{CBB}$ behavior under field conditions, as well

Table 3: C1 contrasts (difference of the different insecticide treatments from the control) of the variable number of berries with live coffee berry borers in each of the seven samplings carried out from January to June. Marechal Floriano, Espírito Santo state, Brazil. 2019.

\begin{tabular}{ll}
\hline Sampling date & Contrasts $\mathrm{C} 1$ \\
\hline January 01 & $C_{1}=10 \widehat{m_{1}}-\widehat{m_{2}}-\widehat{m_{3}}-\widehat{m_{4}}-\widehat{m_{4}}-\widehat{m_{6}}-\widehat{m_{7}}-\widehat{m_{8}}-\widehat{m_{9}}-\widehat{m_{10}}-\widehat{m_{11}}=0.7776^{n s}$ \\
February 10 & $C_{1}=10 \widehat{m_{1}}-\widehat{m_{2}}-\widehat{m_{3}}-\widehat{m_{4}}-\widehat{m_{4}}-\widehat{m_{6}}-\widehat{m_{7}}-\widehat{m_{8}}-\widehat{m_{9}}-\widehat{m_{10}}-\widehat{m_{11}}=8.7728 *$ \\
March 09 & $C_{1}=10 \widehat{m_{1}}-\widehat{m_{2}}-\widehat{m_{3}}-\widehat{m_{4}}-\widehat{m_{4}}-\widehat{m_{6}}-\widehat{m_{7}}-\widehat{m_{8}}-\widehat{m_{9}}-\widehat{m_{10}}-\widehat{m_{11}}=20.3117 *$ \\
April 06 & $C_{1}=10 \widehat{m_{1}}-\widehat{m_{2}}-\widehat{m_{3}}-\widehat{m_{4}}-\widehat{m_{4}}-\widehat{m_{6}}-\widehat{m_{7}}-\widehat{m_{8}}-\widehat{m_{9}}-\widehat{m_{10}}-\widehat{m_{11}}=12.5624 *$ \\
May 04 & $C_{1}=10 \widehat{m_{1}}-\widehat{m_{2}}-\widehat{m_{3}}-\widehat{m_{4}}-\widehat{m_{4}}-\widehat{m_{6}}-\widehat{m_{7}}-\widehat{m_{8}}-\widehat{m_{9}}-\widehat{m_{10}}-\widehat{m_{11}}=13.0885 *$ \\
May 23 & $C_{1}=10 \widehat{m_{1}}-\widehat{m_{2}}-\widehat{m_{3}}-\widehat{m_{4}}-\widehat{m_{4}}-\widehat{m_{6}}-\widehat{m_{7}}-\widehat{m_{8}}-\widehat{m_{9}}-\widehat{m_{10}}-\widehat{m_{11}}=11.475 *$ \\
June 15 & $C_{1}=10 \widehat{m_{1}}-\widehat{m_{2}}-\widehat{m_{3}}-\widehat{m_{4}}-\widehat{m_{4}}-\widehat{m_{6}}-\widehat{m_{7}}-\widehat{m_{8}}-\widehat{m_{9}}-\widehat{m_{10}}-\widehat{m_{11}}=15.4974 *$
\end{tabular}

*Significant by the Scheffé test $(p<0.05)$; nsnot significant.

Table 4: Contrasts of the variable number of berries with live coffee berry borers in the average of the six samplings carried out from February to June, Marechal Floriano, Espírito Santo state, Brazil, 2019.

$$
\begin{gathered}
C_{1}=10 \widehat{m_{1}}-\widehat{m_{2}}-\widehat{m_{3}}-\widehat{m_{4}}-\widehat{m_{4}}-\widehat{m_{6}}-\widehat{m_{7}}-\widehat{m_{8}}-\widehat{m_{9}}-\widehat{m_{10}}-\widehat{m_{11}}=10.686^{*} \\
C_{2}=9 \widehat{m_{2}}-\widehat{m_{3}}-\widehat{m_{4}}-\widehat{m_{4}}-\widehat{m_{6}}-\widehat{m_{7}}-\widehat{m_{8}}-\widehat{m_{9}}-\widehat{m_{10}}-\widehat{m_{11}}=-1.85^{n s} \\
C_{3}=\widehat{m_{7}}-\widehat{m_{8}}=0.0156^{n s} \\
C_{4}=\widehat{m_{3}}+\widehat{m_{9}}+\widehat{m_{10}}-3 \widehat{m_{5}}=0.2718^{n s} \\
C_{5}=\widehat{m_{4}}-\widehat{m_{6}}=0.0336^{n s} \\
C_{6}=\widehat{m_{4}}-\widehat{m_{11}}=-1.202 * \\
C_{7}=\widehat{m_{6}}-\widehat{m_{11}}=-1.2356^{*} \\
C_{8}=2 \widehat{m_{7}}+2 \widehat{m_{8}}-\widehat{m_{3}}-\widehat{m_{9}}-\widehat{m_{10}}-\widehat{m_{5}}=-0.1446^{n s} \\
C_{9}=3 \widehat{m_{7}}+3 \widehat{m_{8}}-2 \widehat{m_{4}}-\widehat{2 m_{6}}-2 \widehat{m_{11}}=-2.2642^{*} \\
C_{10}=3 \widehat{m_{3}}+3 \widehat{m_{9}}+3 \widehat{m_{10}}+3 \widehat{m_{5}}-4 \widehat{m_{4}}-\widehat{4 m_{6}}-4 \widehat{m_{11}}=-4.0946^{*}
\end{gathered}
$$

*Significant by the Scheffé test $(p<0.05)$; nsnot significant. 
as its interactions with climatic factors. Thus, an efficient IPM program integrating several control measures may be implemented (Portilla; Grodowitz, 2018). The previous evaluation carried out immediately before the first spraying of the insecticides revealed that the infestation level found $(2.5 \%-3.5 \%)$ was in agreement or slightly higher than the recommended $(1.0 \%-3.0 \%)$ to start controlling $\mathrm{CBB}$ (Matiello et al., 2020). Monitoring of CBB infestation in Brazil should be carried out during the transit season of $\mathrm{CBB}$ adults which begins three months (November to January) after the largest flowering season in green watery lead berries (Bueno; Carvalho; Silva, 2017). Surveys carried out in Hawaii showed that the peaks of infestations of flying adults occurred close to the harvest time and coincided with the high infestations of berries; however, a large variation in trapping was found within the same property and among properties, with an increase in infestation level in the second and third generation of CBB (Aristizábal et al., 2017a, b).

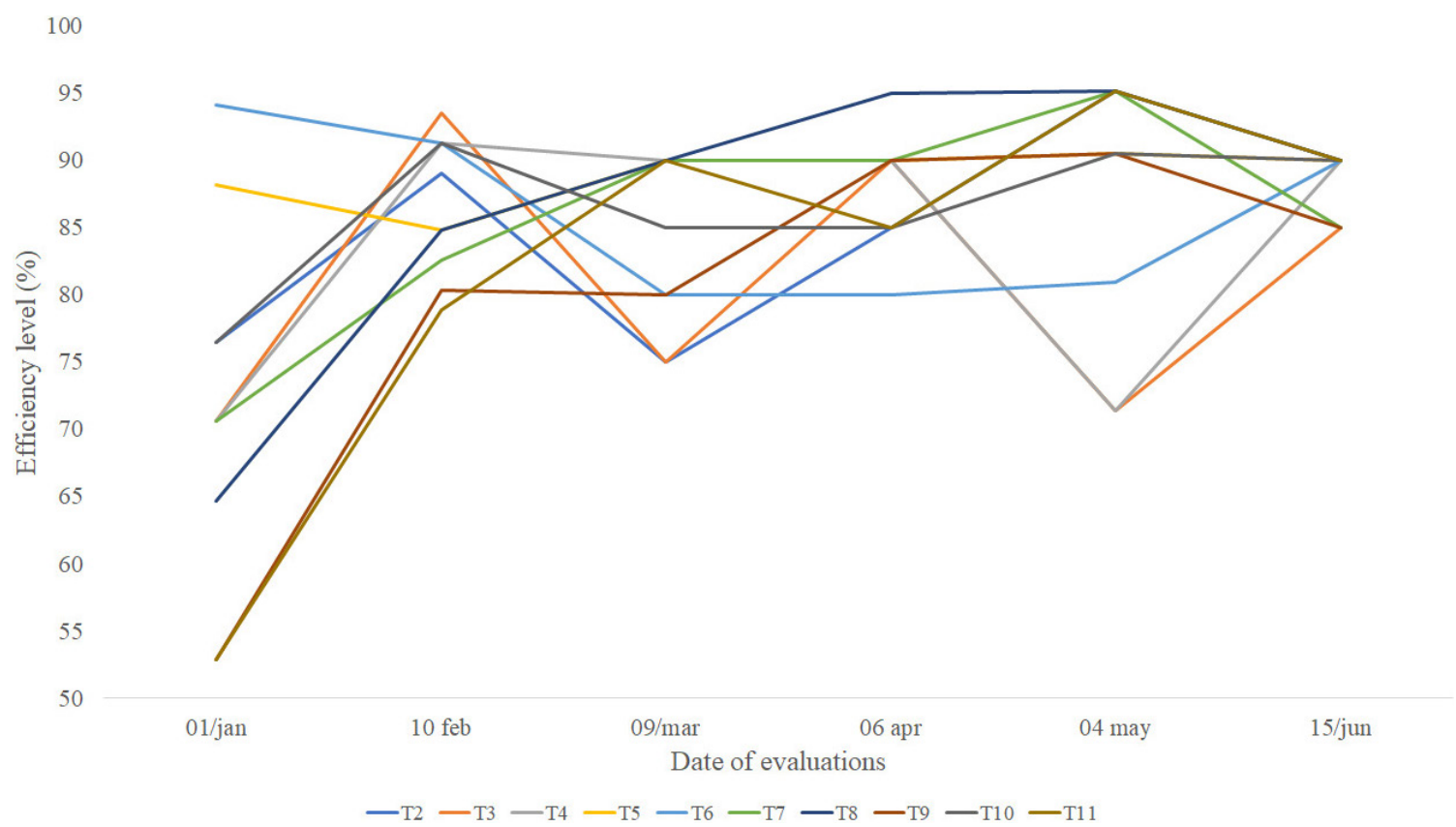

Figure 1: Live CBB infestations level (\%) under field conditions in different treatments for combinations of spraying times and doses of metaflumizone and Beauveria bassina. Marechal Floriano, Espírito Santo state, Brazil. 2019.

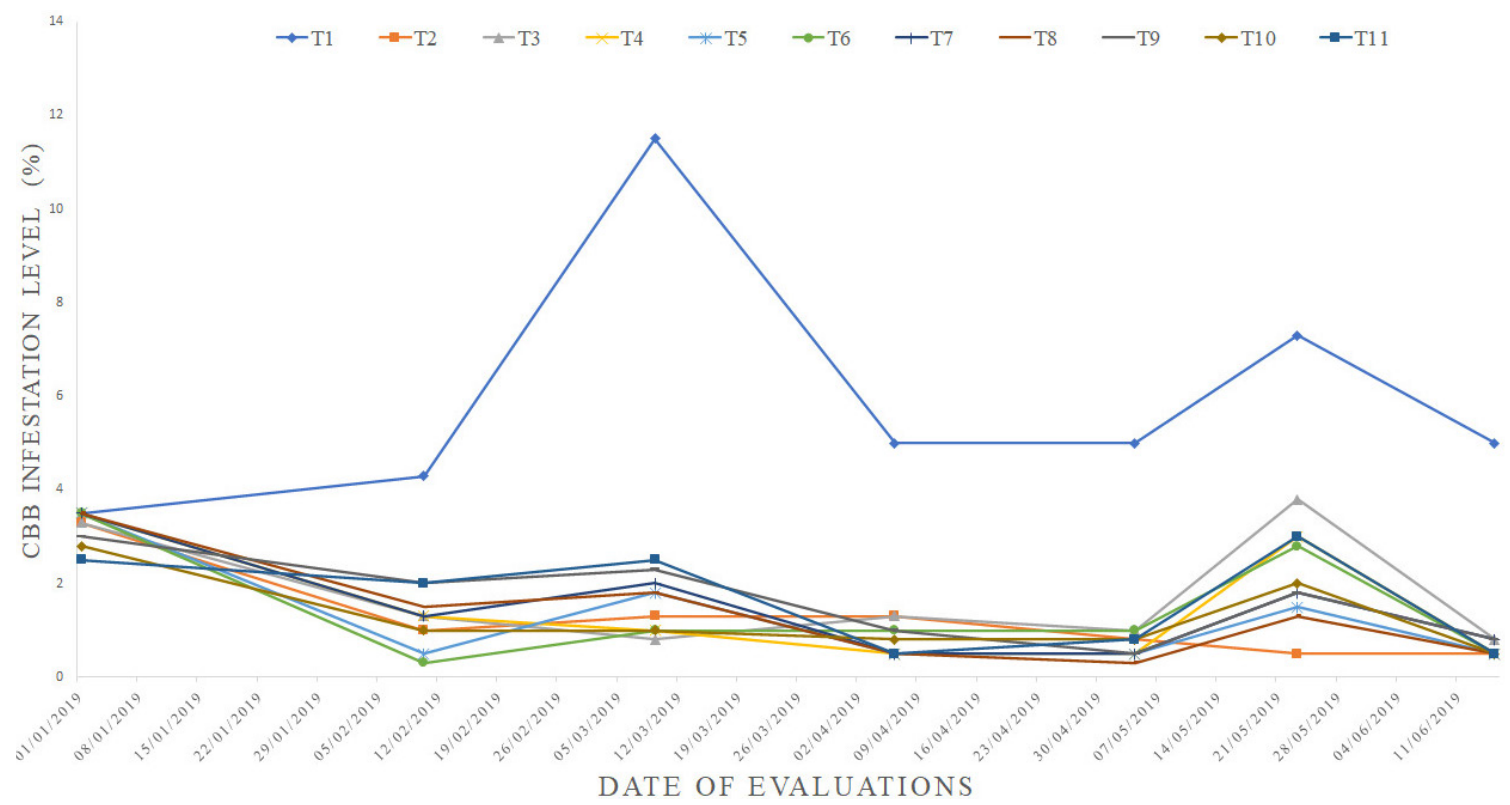

Figure 2: CBB control efficiencies (\% CE) under field conditions in different treatments for combinations of spraying times and doses of metaflumizone and Beauveria bassiana. Marechal Floriano, Espírito Santo state, Brazil. 2019. 
Similarly, the population of $\mathrm{CBB}$ in Brazil is negatively correlated with the intensity of rainfall, and the highest adult populations occur in the dry season (May August) with population peaks at the end of the harvest season (July - August) (Ferreira et al., 2000; Oliveira et al., 2018; Souza; Reis, 1997). The first spraying of insecticides was carried out within the CBB transit season, $\sim 90$ days after the main flowering that occurred from October 7 to November 11, 2018 (Figure 3). The first spraying carried out during this season can be performed using chemical or biological insecticides because they were equally effective in reducing live $\mathrm{CBB}$ infestations in coffee berries. Greater $\mathrm{CE}$ can be obtained if the insecticides are used in more suitable spraying times, such as in the adult CBB transit season. Thus, the beginning of spraying carried out during the CBB transit season (early January 2019) where insects were more exposed to the contact action of metaflumizone and B. bassiana was adequate.

Because of the main source of CBB infestation is the remaining berries, it is necessary to carry out adequate harvesting operations and samplings to monitor $\mathrm{CBB}$ population, particularly at the stages when $\mathrm{CBB}$ has not yet penetrated into the berries ( $\mathrm{AB}$ position) (Aristizábal, 2018). Samplings carried out by the USDA revealed that most of the adult female $\mathrm{CBB}$ found in the $\mathrm{AB}$ position were present in the stage of developing young berries (Aristizábal et al., 2017a). Pereira et al.
(2012) found a positive correlation between the trapping of CBB adults and berries infestation throughout the coffee production cycle and it suggested that the use of alcohol traps for monitoring adults can be as efficient as monitoring infested berries. These traps can be used to monitor CBB adults in flight activity, mainly in the postharvest period until the berries' growth phase (Mariño et al., 2016; Infante, 2018).

As a part of the integrated management of $\mathrm{CBB}$, insecticides such as the active ingredients chlorpyrifos, fenitrothion, fenthion and pirimiphos-methyl have been tested and showed a CBB mortality rate greater than 98\% (Bustillo-Pardey, 2002). Acetomipride + alphacipermethrin, acetomipride + bifenthrin, cyantraniliprole, etiprole, metaflumizone, thiametoxan + clorantraniliprole have also shown good results in reducing the damage caused by CBB. The use of these chemicals for Brazilian coffee have been approved by the Brazilian Ministry of Agriculture, Livestock and Supply (Souza et al., 2013; Agrofit, 2021a). Thus, the importance of the correct time to start spraying as performed in the present study based on the sampling of CBB infestation (Fernandes et al., 2014; Matielo et al. 2020) under field conditions is pointed out. This allows chemical or biological insecticides to directly reach the adult $\mathrm{CBB}$ with a shock effect (contact action) before entering the coffee berries (Metellus; Sampaio; Celoto, 2020).

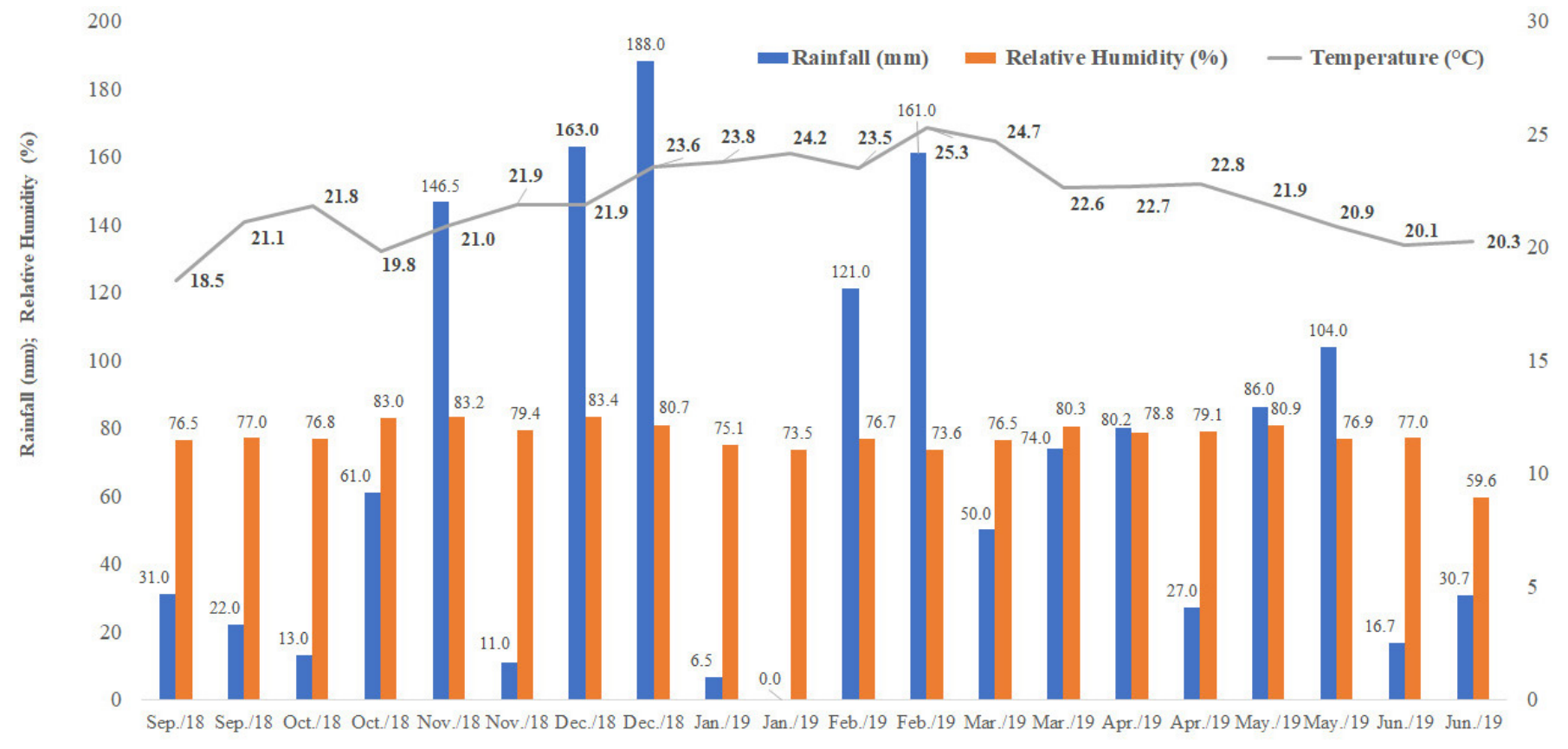

Months/years

Figure 3: Average rainfall $(\mathrm{mm})$, relative humidity $(\%)$ and temperature $\left({ }^{\circ} \mathrm{C}\right)$ by weekly from September 2018 to June 2019 at the experiment site, Marechal Floriano, Espírito Santo state, Brazil. 
An important key associated to the use of chemicals is related to resistance that can be induce in pests and this aspect has been studied in metaflumizone, but not yet to CBB. Resistance to metaflumizone in Plutella xylostella (DBM) was shown to have an autosomal and incompletely recessive mode of inheritance and the resistance selection by metaflumizone did not increased significantly the resistance to other active ingredients such as abamectin, beta-cypermethrin, BT (WG001), chlorantraniliprole, chlorfenapyr, chlorfluazuron, diafenthiuron, methomyl, spinetoram, and spinosad suggesting a lack of cross-resistance. However, a possible cross-resistance to chlorfluazuron, emamectin, indoxacarb and tebufenozide may occur. These cases suggest that the rotated use of metaflumizone with other groups of active ingredients can prevent resistance to metaflumizone, and cross-resistance (Jun et al., 2017; Shen et al., 2020; Sun et al., 2019). Similarly, metaflumizone was studied in Integrated Resistance Management (IRM) strategies for Spodoptera frugiperda in Brazil; authors found that this chemical can be an important tool in insect resistance programs because no cross resistance among it and other Bt proteins, benzoylurea, diamide, pyrethroids, organophosphate, and spinosyn has been detected (Kaiser et al., 2021).

Another worldwide important key to the management of $\mathrm{CBB}$ is the use of the entomopathogenic fungus $B$. bassiana that has been reported for over 20 years as one of the most important entomopathogens for controlling CBB. It is the most common CBB mortality factor corresponding $\sim 10 \%$ of $\mathrm{CBB}$ mortality under field conditions in Colombia; high natural mortality has also been reported in Hawaii, India and Mexico. In areas with ideal conditions of temperature, high humidity and low insolation, B. bassiana can cause high CBB mortality (Góngora; Marín; Benavides, 2009; Haraprasad et al., 2001; Vega et al., 2009; Vega; Infante; Johnson, 2015). Spraying with B. bassiana used in early January together with two other sprayings of metaflumizone in early February and March showed good final results for controlling $\mathrm{CBB}$ in coffee beans in the post-harvest.

The use of metaflumizone or B. bassiana regardless of the doses used in the first spraying or alternating spraying times enabled a reduction $(85 \%-90 \%)$ in the incidence of damaged beans in the post-harvest. The combinations of metaflumizone with $B$. bassiana were effective in spraying from January to March not requiring the 4th spraying in early April to control CBB. Data on infestation in berries and CBB penetration stages can be used to determine the most appropriate time to spray $B$. bassiana based on the IPM guidelines. This fungus is more effective if applied with the adult insect outside the berries (Kawabata; Nakamoto; Curtiss, 2017). Aristizábal et al. (2017a) demonstrated that several sprays of B. bassiana per year are recommended and must coincide with the flight peaks of $\mathrm{CBB}$ adults and most sprayings must be carried out at an earlier stage of berry development. These authors also observed that the highest mortality rates were found in conditions of higher humidity allowing the development of the fungus. Temperature, rainfall and relative humidity vary significantly with altitude and can play a very important role in population dynamics (Aristizábal et al., 2017a) and in the effectiveness of B. bassiana. The highland region where our study was carried out showed conditions for the use of microbial control in almost the entire coffee production season, including November and December when CBB should also be monitored (Figure 3).

The best association of $B$. bassiana to metaflumizone for CBB control was the use of the dose of $2.0 \mathrm{~kg} \mathrm{ha}^{-1}$ sprayed in early March 2019. During this period, rainfall varied between 161 and $50 \mathrm{~mm}$ (total $=211 \mathrm{~mm}$ ), values considered satisfactory for the fungus to act. The climate may have influenced the $\mathrm{CE}$ of the biological insecticide used in early January spraying, since the total precipitation in this month was very low, totaling 6.5 $\mathrm{mm}$. Although, the relative humidity was $>60 \%$ and the mean temperature ranged from 23.6 to $25.3{ }^{\circ} \mathrm{C}$ (Figure 3), suitable for the development and colonization of this fungus (Agrofit, $2021 b$ ). The entomopathogenic fungus $B$. bassiana has been found to be an important factor in the management of CBB, but its $\mathrm{CE}$ is conditioned by environmental factors (Neves; Hirose, 2005; Mota et. al., 2017). Wraight et al. (2018) reported that the highest activity of wild $B$. bassiana strains in Hawaii was found in locations $>500 \mathrm{~m}$ altitude and infection rates did not exceed $4 \%$ on low-altitude farms $(<300 \mathrm{~m})$. This aspect is not a limitation for the use of this fungus in the highlands of Espírito Santo state, where the altitudes in all areas where coffee is cultivated are $>500 \mathrm{~m}$ reaching $1,400 \mathrm{~m}$. Also, the CE of this fungus is conditioned by the position of entry of $\mathrm{CBB}$ female in the berry. When the adult insect still has part of its body in the external area of the berry, colonization is greater and consequently increases $\mathrm{CE}$. More the $\mathrm{CBB}$ female penetrates into the berry lower is CE (Greco et al., 2018; Vera et al., 2011).

However, metaflumizone have been related with a strong inhibition on $B$. bassiana when used in mixture. This chemical when used combined with $B$. bassiana showed no difference in the cumulative mortality of Phauda flammans (Walker), a lepidopteran defoliator of Ficus spp., when compared to metaflumizone alone. This sug g ests that the degradation products of metaflumizone may have caused the inhibition of $B$. bassiana. Thus, mixing these two active ingredients should be avoided to prevent $B$. bassiana from losing its effect (Chen et al., 2021). In the other hands, no limitations have been reported on their use in spraying rotation, as used in our study.

New insecticides can be use $d$ to replace endosulfan and have less environmental impact using a CBB Integrated Management program. However, the new chemical and biological insecticides do not have the mode of action of endolsufan (Naqvi; Vaishnavi, 1993) in CBB. Thus, the mandatory integration of control methods knowledge of CBB's bioecology and monitoring its population through samp ling of berries with adult entry position or by alcohol trapping need to be disseminated to coffee 
farmers. The chemical and the biological insecticides used should be tools and first spray must be done at the early beginning of infestations and only if ne cessary (Hollingsworth et al., 2020; Johnson; Manoukis, 2020; Johnson et al., 2020).

\section{CONCLUSIONS}

Metaflumizone at a total dose of $3.5 \mathrm{~L} \mathrm{ha}^{-1}$ showed high performance to control $\mathrm{CBB}$ under field conditions in high altitude regions.

Two foliar sprayings of metaflumizone from January to March regardless of the doses and spraying times were enough to control $\mathrm{CBB}$.

The association of metaflumizone with $B$. bassiana reduced an average of $88.5 \% \mathrm{CBB}$ infestation of postharvested coffee beans and can be used as one of the tools for the Integrated Management of CBB under field conditions.

Beauveria bassiana can be associated with metaflumizone to control $\mathrm{CBB}$ as a complementary spray in March and at a dose of $2.0 \mathrm{~kg} \mathrm{ha}^{-1}$ should be also used as a tool for the Integrated Management of CBB under field conditions.

The monitoring of CBB population must be carried out and the first spraying with chemical or biological insecticide must be started mainly at the recommended control level and in the transit season of CBB when adults are more exposed.

\section{AUTHORS' CONTRIBUTIONS}

CAK performed the experiment, co-work and review the final version of the manuscript, MJF supervised the experiment, performed references review, wrote and approved the final version of the manuscript, PLPM performed the experiment and review the final version of the manuscript, RCG conducted all statistical analyses and review the final version of the manuscript, DSM co-work and review the final version of the manuscript, FTA performed the experiment and review the final version of the manuscript, RSD performed the experiment, FLMR review and approved the final version of the manuscript.

\section{CONFLICT OF INTEREST}

The authors declare that there is no conflict of interest.

\section{REFERENCES}

ABBOTT, W. S. A method of computing the effectiveness of an insecticide. Journal of Economic Entomology, 18(2):235-237, 1925.

AGROFIT. Sistema de agrotóxicos fitossanitários. 2021a. Available in: <http://agrofit.agricultura.gov. br/agrofit_cons/principal_agrofit_cons.> Access in: September, 24, 2021.
AGROFIT. Sistema de agrotóxicos fitossanitários. Boveril WP PL63. 2021b. Available in: <http://agrofit.agricultura. gov.br/agrofit_cons/!ap_produto_form_detalhe cons?p_id_produto_formulado_tecnico $=5496 \&$ p_tipo_ janela $=\mathrm{NEW}>$. Access in: September, 24, 2021.

ALIXANDRE, F. T. et al. Cafeicultura sustentável: Boas práticas agrícolas para o café arábica. Vitória, ES: Incaper, 2020. 48 (Incaper, Documentos, 269).

ARISTIZÁBAL, L. F. Controlling the coffee berry borer through integrated pest management: A practical manual for coffee growers and field workers in Hawaii. Kailua-Kona, Hawaii (USA), 2018.79p.

ARISTIZÁBAL, L. F. et al. Integrated pest management of coffee berry borer in Hawaii and Puerto Rico: Current status and prospects. Insects, 8(4):123, $2017 \mathrm{a}$.

ARISTIZÁBAL, L. F. et al. Flight activity and field infestation relationship for coffee berry borer Hypothenemus hampei (Ferrari) in commercial coffee plantations in Kona and Kau Districts, Hawaii. Journal of Economic Entomology, 110(6):2421-2447, 2017 b.

BARRERA, J. F. Coffee pest and their management. In: CAPINERA, J. L. (Ed.). Encyclopedia of entomology. 2nd ed. New York, NY: Springer. p. 961-998, 2008.

BUENO, A. F.; CARVALHO, G. A.; SILVA, D. M. Pesticide selectivity to natural enemies: challenges and constraints for research and field recommendation. Ciência Rural, 47(6):1-10, 2017.

BUSTILLO-PARDEY, A. E. EI manejo de cafetales y su relación con el control de la broca del café en Colombia. Cenicafé, 2002. 40p (Boletin Tećnico $\mathbf{n}^{\circ} \leqslant$ r).

CHEN, X.-M. et al. Use of Beauveria bassiana in combination with commercial insecticides to manage Phauda flammans (Walker) (Lepidoptera: Phaudidae): Testing for compatibility and synergy. Journal of AsiaPacific Entomology 24(2):272-278, 2021.

COMPANHIA NACIONAL DE ABASTECIMENTO - CONAB. Acompanhamento da safra brasileira de café - Safra 2020. 2020. Brasília. Available in: <https://www.conab.gov.br/infoagro/safras/cafe>. Access in: April, 25, 2021.

EMPRESA BRASILEIRA DE PESQUISA AGROPECUÁRIA - EMBRAPA. Sistema Brasileiro de Classificação de Solos. 3ed. Brasília, DF: Embrapa, Brasil. 2013. 356p.

FERNANDES, F. L. et al. Controle massal da broca-do-café com armadilhas de garrafa pet vermelha em cafeeiro. Pesquisa Agropecuária Brasileira, 49(8):587-59. 2014. 
FERREIRA, A. J. et al. Dinâmica populacional da brocado-café Hypothenemus hampei (Ferr.) (Coleoptera: Scolytidae) em Lavras, MG. Anais da Sociedade Entomológica do Brasil, 29(2):237-244, 2000.

FORNAZIER, M. J. et al. Integrated pest management in conilon coffee. In: FERRÃO, R. G. et al. (Eds.). Conilon coffee. 1ed. Vitoria, ES: v. 1, p. 493-533. 2019.

GÓNGORA, C. E.; MARÍN, P.; BENAVIDES, P. Claves para el éxito del hongo Beauveria bassiana como controlador biológico de la broca del café. p. 1-8, 2009. (Avance técnico, 348).

GRECO, E. B. et al. Efficacy of Beauveria bassiana applications on coffee berry borer across an elevation gradient in Hawaii. Biocontrol Science and Technology, 28(11):995-1013, 2018.

HARAPRASAD, N. et al. Beauveria bassiana - A potential mycopesticide for the efficient control of coffee berry borer, Hypothenemus hampei (Ferrari) in India. Biocontrol Science and Technology, 11(2):251-260, 2001.

HOLLINGSWORTH, R. G. et al. Incorporating Beauveria bassiana into an integrated pest management plan for coffee berry borer in Hawaii. Frontiers in Sustainable Food Systems, 4(22):35675, 2020.

INFANTE, F. Pest management strategies against the coffee berry borer (Coleoptera: Curculionidae: Scolytinae). Journal of Agricultural Food Chemistry, 66:5275-5280, 2018.

JOHNSON, M. A.; MANOUKIS, N. C. Abundance of coffee berry borer in feral, abandoned and managed coffee on Hawaii Island. Journal of Applied Entomology, 144:920-928, 2020.

JOHNSON, M. A. et al. Coffee berry borer (Hypothenemus hampei), a global pest of coffee: Perspectives from historical and recent invasions, and future priorities. US Pacific Basin Agricultural Insects, 11(12):882, 2020.

JUN, S. et al. Fitness and inheritance of metaflumizone resistance in Plutella xylostella. Pesticide Biochemistry and Physiology 139:53-59, 2017.

KAISER, I. S. et al. Baseline response, monitoring, and cross-resistance of Spodoptera frugiperda (lepidoptera: noctuidae) to sodium channel blocker. Journal of Economic Entomology, 114(2):903-913, 2021.

KAWABATA, A. M.; NAKAMOTO, S. T.; CURTISS, R. T. Recommendations for coffee berry borer integrated pest management in Hawai'i 2016. Insect Pests IP-41. College of Tropical Agriculture and Human Resources, University of Hawai'i: Honolulu, HI, USA, p. 24, 2017.
MARIÑO, Y. A. et al. Sun vs. shade affects infestation, total population and sex ratio of the coffee berry borer (Hypothenemus hampei) in Puerto Rico. Agriculture, Ecosystems \& Environment, 222:258-266. 2016.

MATIELLO, J. B. et al. Cultura de café no Brasil. Manual de Recomendações. $2^{\mathrm{a}}$ ed. Varginha, MG: Fundação Procafé, 2020, 716p.

METELLUS, D.; SAMPAIO, M. V.; CELOTO, F. J. 2020. Activity of insecticides on coffee berry borer, Hypothenemus hampei (Coleoptera: Curculionidae, Scolytinae). Bioscience Journal, 36(4):1099-1115, 2020.

PEREIRA, A. E. et al. Correlation between numbers captured and infestation levels of the coffee berry borer, Hypothenemus hampei: A preliminary basis for an action threshold using baited traps. International Journal of Pest Management, 58(2):183-190, 2012.

PORTILLA, M.; GRODOWITZ, M. Abridged life tables for Cephalonomia stephanoderis and Prorops nasuta (Hymenoptera: Bethylidae) parasitoids of Hypothenemus hampei (Coleoptera: Curculionidae: Scolytinae) reared on artificial diet. Journal of Insects Science, 18(2):1-7, 2018.

MOTA, L. H. C. et al. Autoinoculation trap for management of Hypothenemus hampei (Ferrari) with Beauveria bassiana (Bals.) in coffee crops. Biological Control, 111: 32-39, 2017

NAQVI, S. M.; VAISHNAVI, C. Bioaccumulative potential and toxicity of endosulfan insecticide to non-target animals. Comparative Biochemistry and Physiology, 105(3):347-361, 1993.

NEVES, P. M. O. J.; HIROSE, E. Seleção de isolados de Beauveria bassiana para o controle biológico da brocado-café, Hypothenemus hampei (Ferrari) (Coleoptera: Scolytidae). Neotropical Entomology, 34(3):77-82, 2005.

MONTOYA, S.; CÁRDENAS, M. R. Biología de Hypothenemus hampei (Ferrari) en frutos de café de diferentes edades. Revista Cenicafé, 45(1):5-13, 1994.

OLIVEIRA, C. M. et al. Coffee berry borer in conilon coffee in the Brazilian Cerrado: An ancient pest in a new environment. Bulletin of Entomological Research, 108(1):101-107, 2018

R CORE TEAM. R: A language and environment for statistical computing, version 4.0.5. Viena, Austria: R Foundation for Statistical Computing. Available in: $<$ https://www.R-project.org>. Access in: April, 02, 2021. 
REIS, P. R.; SOUZA, J. C. Manejo integrado das pragas do cafeeiro. In: REIS, P. R.; CUNHA, R. L. Café arábica: Do plantio à colheita. Minas Gerais, MG: Epamig, p. 573688, 2010.

SALGADO, V. L.; HAYASHI, J. H. Metaflumizone is a novel sodium channel blocker insecticide. Veterinary Parasitology, 150(3):182-189. 2007.

SHEN, J. et al. Biochemical mechanisms, cross-resistance and stability of resistance to Metaflumizone in Plutella xylostella. Insects, 11(5):311, 2020.

SOUZA, J. C.; REIS, P. R. Broca-do-café: Histórico, reconhecimento, biologia, prejuízos, monitoramento e controle. 2ed. Minas Gerais, MG: Epamig, 1997. 40p. (Boletim Técnico, 50).

SOUZA, J. C. et al. Controle químico da broca-do-café com cyantraniliprole. Coffee Science, 8(4):404-410, 2013.

SUN, X. X. et al. Resistance risk evaluated by metaflumizone selection and the effects on toxicities over other insecticides in Spodoptera exigua (Lepidoptera: Noctuidae). Journal of Economic Entomology, 112(5):2354-2361, 2019.
VEGA, F. E. et al. The coffee berry borer, Hypothenemus hampei (Ferrari) (Coleoptera: Curculionidae): A short review, with recent findings and future research directions. Terrestrial Arthropod Reviews, 2(2):129147, 2009.

VEGA, F. E.; INFANTE, F.; JOHNSON, A. J. The genus Hypothenemus, with emphasis on $H$. hampei, the coffee berry borer. In: VEGA, F. E.; HOFSTETTER, R. (Eds.). Bark beetles: Biology and ecology of native and invasive species. San Diego, CA: Academic Press, p. 427-494, 2015.

VERA, J. T. et al. Evaluation of Beauveria bassiana (Ascomycota: Hypocreales) as a control of the coffee berry borer Hypothenemus hampei (Coleoptera: Curculionidae: Scolytinae) emerging from fallen infested berries on the ground. Biocontrol Science and Technology, 21(1):1-14, 2011.

WRAIGHT, S. P. et al. Prevalence of naturally-occurring strains of Beauveria bassiana in populations of coffee berry borer Hypothenemus hampei on Hawaii Island, with observations on coffee plant- $H$. hampei-B. bassiana interactions. Journal of Invertebrated Pathology, 156:54-72, 2018. 